genius of a Grant may be associated with an inability to acquire or even retain wealth. Inventions which have added enormously to the wealth of the nation have been made by men so poor that they were obliged to borrow money for living expenses. A prominent patent attorney with much experience recently said to me that he thought inventors as a class were without business ability, that is, without the ability to turn advantageously the product of their brains into money by means of which they could have leisure to do other work. No one can say how much the world has lost by the inability of the properly qualified men to give their best thought to discovery and invention. Had such a fund as that given for research by $\mathrm{Mr}$. Carnegie been available in the past and been properly administered, the human race would in my opinion have been transformed into something immensely better than we have at present.

Hence, I believe that research funds, instead of prohibiting the payment of the personal expenses of the investigator, should be mainly devoted to the payment of such expenses, so that the investigator might be allowed to devote his whole time and his best thought to the investigation, even if for only a short time.

The funds thus administered would have plenty of applicants, and much work would be thrown on the trustees in seeing that the appropriations were made to the proper persons and properly used, but this is a task I think the trustees ought to assume.

Hyde Park, Mass.,

H. H. Clayton.

Jan. 21, 1902.

\section{A RARE 'WHALE SHaRK.'}

To the Editor of Science: The National Museum has obtained a skin of a rare 'whaleshark,' Rhinodon, from an eighteen-foot specimen found on the beach three miles north of Ormond, Florida, January 25, 1902, this being the first record of the occurrence of the genus on the Atlantic coast of America. The Museum is indebted to Messrs. Anderson and Price, managers of the Hotel Ormond, who telegraphed the discovery to the Smithsonian Institution and later had the skin removed and shipped to Washington under instructions from Dr. F. W. True, Head Curator, Department of Biology.

Rhinodon typicus was first figured and described by Dr. Andrew Smith in his illustrations of the zoology of South Africa, in 1841, the type being a sixteen-foot example found at the Cape of Good Hope.* Another one of this species taken at the Seychelle Ids. is known from the teeth only.t

A genus related to Rhinodon was described by Dr. Theodore Gill in the proceedings of the Academy of Natural Sciences of Philadelphia, 1865, p. 177, under the name Micristodus, from jaws, vertebræ and notes, received by the Smithsonian Institution in 1858, from Captain Stone, and taken from a twenty-foot shark captured in the Gulf of California, where it was known as the 'Tiburon ballenas,' or 'Whale Shark.'

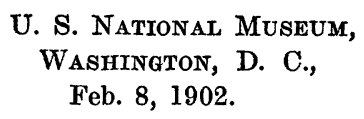

RECENT PROGRESS IN GLACIOLOGY.

OuR knowledge concerning glaciers past and present is gradually being extended by local studies in various parts of the earth. For several years, systematic effort has been made to record observations on the movements of existing glaciers for the sake of determining the conditions and laws governing their advance and retreat. Harry Fielding Reid has published a number of articles bearing on this general topic in recent years. The last of these articlesł presents a summary of existing knowledge on the present phases of glacier movement in various parts of the world, with reference to advance and retreat.

Most of the glaciers of the Swiss Alps are retreating. In the eastern Alps about one half are retreating, while about one fourth are stationary, and nearly as many advancing. In

* Preserved in the Museum of the Jardin des Plantes, Paris.

$\dagger$ British Museum.

\$'Variations of Glaciers,' Journal of Geology, Vol. IX., pp. 250-254. 
other parts of the Alps retreat is the rule. The meager records from Scandinavia indicate general retreat for the glaciers which have been under observation. The few available records from the United States (including Alaska), Canada, Greenland and Russian Asia indicate the same phase of glacier movement. In the Himalayas there has been little change observed in recent years. More extensive observations, carried on through long periods of time, are much to be desired.

A significant conclusion has been reached by Myron L. Fuller* in his studies of the glacial drift of eastern Massachusetts. $\mathrm{He}$ finds evidence of two distinct sheets of till, the lower being differentiated from the upper, both physically and lithologically. The physical difference is such as to indicate that the underlying sheet of till was subjected to extensive decay before the overlying sheet was deposited. This conclusion is in harmony with the recent interpretations put upon the drift in other parts of the State by other geologists, and with the interpretations which have long been given to the drift of the Mississippi basin.

Glaciation has been determined $†$ in Siberia between the parallels of $35^{\circ}$ and $36^{\circ}$, and near the $93 \mathrm{~d}$ meridian there is evidence of glaciation in an area about one hundred square miles in extent. Among the glacial features are drumlins and cirques. Elsewhere cirques occur in the high Altais, and glaciers are now found in the same mountains about the sources of the Irtish River, near the Mongolian border, at elevations of about 10,000 feet.

Several points of interest in connection with the Pleistocene glaciers in the western part of the United States have been determined during the past year. $\$$

Mr. Wallace W. Atwood has been studying the glacial drift of the Wasatch mountains, and has determined the positions of 50 Pleistocene glaciers exceeding a mile in length. Of

* Probable Representatives of Pre-Wisconsin Till in Southeastern Massachusetts,' Jour. of Geol., Vol. IX., pp. 311-329, 1901.

$\dagger$ 'A Single Occurrence of Glaciation in Siberia,' Am. Geol., Vol. XXVII., pp. 45-47, 1901.

\$ Glacial Work in the Western Mountains in 1901,' by Rollin D. Salisbury. Jour. of Geol., Vol. IV., pp. 718-73i. these, ten exceeded five miles in length; fourteen descended to an altitude of less than 6,000 feet, and seven to an altitude of 5,000 feet. Seven of these glaciers reached the shore-line of Lake Bonneville. The elevation necessary to give rise to a glacier was about 9,000 feet. Mr. Atwood and his party also found that the drift of the Wasatch mountains is referable to two distinct epochs of glaciation. In the valley of the North Fork of the American Fork, the two sheets of drift, produced by glaciation from nearly opposite directions, are separated by a soil thicker than that which covers the surface of the upper sheet of drift. Other evidences of the duality of the glacial period in this region are found in the unequal weathering to which different parts of the drift have been subjected, and in the unequal amount of erosion which the drift of different localities has suffered.

Pleistocene glaciation has been determined in the mountains of New Mexico near Santa Fe. The glaciation, so far as determined, was between the parallels $35^{\circ} 45^{\prime}$, and $36^{\circ}$, and between the meridians of $105^{\circ} 35^{\prime}$ and $105^{\circ}$ $50^{\prime}$. Within this area, the positions of something like 50 Pleistocene glaciers have been determined, chiefly by Messrs. John Webb and William A. Averill. Study was carried far enough to indicate that local glaciation was the rule, in the vicinity of altitudes reaching or exceeding 12,000 feet. Some of the glaciers reached a length of several miles. The glacial features found in this region are such as are developed by small mountain glaciers.

Pleistocene glaciers were found to have existed on the north slopes of the Spanish Peaks of Colorado. The glaciers here were less extensive than might have been anticipated from the elevation of the mountains, but their small size is probably the result of the small extent of the areas attaining the requisite height.

In northwestern Montana, east of the Rocky mountains, Mr. F. H. H. Calhoun has studied the relations of the drift deposited by the Keewatin ice sheet to that deposited by the glaciers coming out to the eastward from the mountains. It appears from his work that the Wisconsin drift extended somewhat farther to the westward than has been supposed, reach- 
ing nearly to the Rockies in the region mentioned. The drift of the northeastern ice sheet overlapped that coming from the mountains, just south of the 49 th parallel. This relation of the two bodies of drift shows that the continental ice sheet reached its most advanced position after the valley glaciers from the west had retreated. There is no evidence, however, that the interval between the deposition of the two bodies of drift was considerable. The Sweet Grass Hills, just south of the 49th parallel, and thirty miles back from the edge of the ice sheet, were nunataks. The slope of the surface of the continental ice sheet between its edge and the Sweet Grass Hills is estimated to have been about 50 feet per mile. A long narrow lake existed in front of the Keewatin ice sheet, the standing water resulting from the obstruction of drainage by the ice. The present drainage of the region is in many respects notably different from that which obtained in pre-glacial times.

Messrs. George Garrey and Eliot Blackwelder, partly in company with the writer and partly alone, made a number of determinations with reference to Pleistocene glaciation west of the Rockies and east of the Cascades. The boundaries of the Okanogan or Coulee City (Wash.) ice lobe, south and east of the Columbia River, were traced out. This ice lobe had previously been made known by Russell, and its general limits indicated. Messrs. Garrey and Blackwelder also determined the existence of a great glacier down the valley of the Columbia just west of the 118th meridian. This glacier descended the valley of the Columbia to the point where the Spokane River comes in. The eastern margin of this glacier looped northward around Huckleberry Mountain (Tp. 32, R. 38 E.), and to the east of this point another glacier descended the valley of the Colville River. These two glaciers were, therefore, separated only at their southern ends, becoming continuous to the north. The eastern margin of the Colville glacier, which descended to Springdale, probably connects around Old Dominion Mountain with the ice which descended the Pend d'Oreille valley. The ice of this valley descended southward to a point three miles southwest of
Davis Lake. A few data were also gathered concerning glaciation at points farther east.

Extensive deposits of loess were found in eastern Washington and northeastern Oregon. In geographic distribution, the loess corresponds, in a general way, with the wheatgrowing areas of these States. Beds of volcanic ash are sometimes interbedded with the loess. Some of the loess, how much was not determined, had an æolian origin.

Rolidin D. Salisbury.

\section{RECENT ZOOPALEONTOLOGY.}

A FOSSIL CAMEL FROM SOUTHERN RUSSIA.

Professor Nehring,* of Berlin, describes the skull of a Pleistocene camel from beds along the Volga, in the same state of preservation as the mammoth, wild horse, reindeer and Elasmotherium. From the distribution of this and other Pleistocene camels in Roumania and Algiers, the author agrees with the view expressed by Lehmann (1891) that the dromedary and Bactrian camel originated in two distinct regions, the former being a subtropical steppe and desert animal, the latter belonging to the subarctic steppes and deserts.

Fossil REMAINS OF LAKE CALILABONa.

E. C. StiRLing, $†$ director of the South Australian Museum, opens a series of memoirs on the large deposit of fossil bones discovered in the bed of Lake Callabona, South Australia, first reported in Nature in 1894 . The present memoir is devoted to the manus and pes of Diprotodon, the largest and most abundant marsupial in this remarkable deposit. The salt clay in which the bones were embedded was always wet, the necessary excavations soon filling with water. Nevertheless fourteen feet were removed en masse within large balls of the matrix clay. Besides the great difficulties of removal the fossils had to be carried two hundred miles to a railway station, by camel

\footnotetext{
* 'Ein fossiles Kamel aus Südrufsland, nebst Bemerkungen über die Heimat der Kamele,' Sonderabdr. aus dem Globus, Bd. LXXX., Nr. 12, pp. 188-189.

$\dagger$ 'Fossil Remains of Lake Callabona', Part I. Mem. Roy. Soc. S. Australia, Vol. I., Part I., pp. 1-40, PI. I.-XVIII., 4to. Adelaide, 1899.
} 